\title{
RENDIMENTO DA VARIEDADE DE FEIJÃO 'FT BONITO' NA COMBINAÇÃO DE SISTEMAS DE SEMEADURA, POPULAÇÕES DE PLANTAS E DOSES DE NITROGÊNIO
}

\author{
YIELD OF THE VARIETY OF BEAN ' FT BONITO' IN THE \\ COMBINATION OF SYSTEMS OF SOWING, POPULATIONS \\ OF PLANTS AND DOSES OF NITROGEN
}

\author{
Sixto Hugo Rabery CÁCERES \\ Orientador(a): Prof. Dr. Pedro RONZELLI JÚNIOR \\ (Departamento de Fitotecnia e Fitossanitarismo)
}

\begin{abstract}
RESUMO
Durante o ano agrícola 1998/99 foram conduzidos, na Estação Experimental do Cangüiri, da Universidade Federal do Paraná, em Pinhais, PR, quatro experimentos com o objetivo de encontrar a combinação de manejo da cultura do feijoeiro que melhor permita explorar o potencial de rendimento da cultura nos sistemas de produção por semeadura convencional e direta. Buscou-se determinar a população de plantas, o espaçamento entre fileiras, a dose de nitrogênio e a combinação de população de plantas e doses de nitrogênio para maior rendimento. O solo da área é classificado como um Latossolo Vermelho-Amarelo Álico. O local foi anteriormente cultivado com milho e com aveia preta. O delineamento experimental utilizado foi o de blocos ao acaso com 16 tratamentos, produto do arranjo fatorial de quatro populações de plantas $(285,427,570$ e 712 mil plantas) com quatro níveis de adubação nitrogenada $(0,40,80$ e $120 \mathrm{~kg} \cdot \mathrm{ha}^{-1}$ ), em quatro repetições. Dois experimentos eram em semeadura convencional e dois em semeadura direta considerados os espaçamentos, entre fileiras, de 0,35 m e 0,50 m, utilizando-se a variedade de feijão 'FT Bonito', de hábito de crescimento indeterminado, tipo II, porte semi-ereto, tegumento de cor creme com listas havana, do grupo carioca. As parcelas experimentais dos experimentos com espaçamento de $0,35 \mathrm{~m}$, entre fileiras, eram compostas de seis fileiras, considerando-se as quatro centrais como área útil, e as dos experimentos com $0,50 \mathrm{~m}$ eram compostas de quatro fileiras, considerando-se as duas centrais como área útil. Os resultados mostraram que espaçamentos de 0,50 m entre fileiras apresentaram tendência de aumento no rendimento de grãos, em ambos os sistemas de semeadura. Mostraram também que não houve diferenças significativas no rendimento entre as populações de plantas nem entre doses de nitrogênio. Conclui-se que as populações de plantas para melhor explorar o potencial de rendimento estão entre 200 e 400 mil plantas por hectare com espaçamento de $0,50 \mathrm{~m}$, entre fileiras, em ambos os sistemas de semeadura.
\end{abstract}

\begin{abstract}
During the growing season of the 1998/99 year, four field experiment was carried out, at the Cangüiri Experiment Station of the Universidade Federal do Paraná, at Pinhais, PR, with the objective to get the best combination of crop management for dry bean yield in conventional and no tillage cropping systems. It was desired to determinate the plant population, the rows spacing, the nitrogen doses and the combination in between plant population and nitrogen doses to get better yield. The soil is classified as one Latossolo VermelhoAmarelo Álico. In the last year, the area was cultivated with maize and oat. The experimental design utilized was a randomized complete block with 16 treatments, from the factorial arrangement of four plants population $(285,427,570$ and 712 thousands of plants) with four nitrogen doses $\left(0,40,80\right.$ and $\left.120 \mathrm{~kg} \cdot \mathrm{ha}^{-1}\right)$. Two experiments were in conventional cropping system and two under no-tillage, considering $0.35 \mathrm{~m}$ and $0.50 \mathrm{~m}$ between rows and utilizing "FT Bonito" bean variety, an indeterminate one, type II semi-erect growth habit, cream coat color with havana list, carioca commercial group. The plots in the $0.35 \mathrm{~m}$ row experiment, had six rows, considering the central four as utility area, and the plots in the $0.50 \mathrm{~m}$ had four rows, considering the central two as utility area. The results showed that grain yield in the $0.50 \mathrm{~m}$ row experiments increase in the two cropping systems. It showed also that there were no significant interference of plant population neither of the nitrogen doses. The conclusion is that the plant population, to better explore the bean yield potential, is between 200 and 400 thousand plants per hectare with $0.50 \mathrm{~m}$ between rows, for both cropping systems.
\end{abstract}

